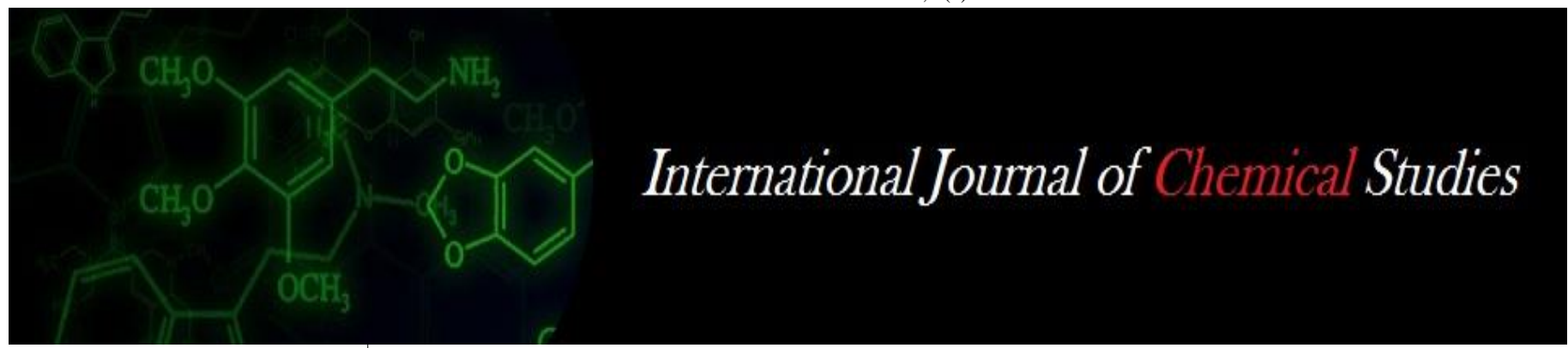

P-ISSN: 2349-8528

E-ISSN: 2321-4902

IJCS 2020: 8(1): 119-124

(C) 2020 IJCS

Received: 16-11-2019

Accepted: 19-12-2019

Sarthak Kiribhaga

Department of Post-Harvest

Technology College of

Horticulture, Vellanikkara

Kerala Agricultural University,

Thrissur, Kerala, India

Saji Gomez

Department of Post-Harvest

Technology College of

Horticulture, Vellanikkara

Kerala Agricultural University,

Thrissur, Kerala, India

Meagle Joseph

Department of Post-Harvest

Technology College of

Horticulture, Vellanikkara

Kerala Agricultural University,

Thrissur, Kerala, India

Surendra Gopal

Department of Post-Harvest

Technology College of

Horticulture, Vellanikkara

Kerala Agricultural University,

Thrissur, Kerala, India

Seeja Thomachan Panjikkaran

Department of Post-Harvest

Technology College of

Horticulture, Vellanikkara

Kerala Agricultural University,

Thrissur, Kerala, India

Corresponding Author: Sarthak Kiribhaga

Department of Post-Harvest

Technology College of

Horticulture, Vellanikkara

Kerala Agricultural University,

Thrissur, Kerala, India

\section{Biochemical changes of banana wine during storage}

\author{
Sarthak Kiribhaga, Saji Gomez, Meagle Joseph, Surendra Gopal and Seeja \\ Thomachan Panjikkaran
}

\begin{abstract}
Wine was prepared from banana varieties (Grand Naine, Karpooravalli, Poovan, Yangambi (KM-5) and Palayankodan). Banana wine was stored in plain and amber coloured bottles under ambient conditions for three months. After one month of storage, $\mathrm{pH}$ and alcohol content showed an increasing trend whereas titratable acidity, total soluble solids, ascorbic acid, total phenols and microbial population showed a decreasing trend. Same trend continued even after two months of storage. At the end of storage period, the total soluble solids and alcohol content remained stable without showing any variation in their values as that of the previous month whereas $\mathrm{pH}$ showed an increasing trend. Titratable acidity, ascorbic acid, phenols and microbial population showed a decreasing trend. Colour retention was better in amber coloured bottles. Wine from the variety Poovan had the highest overall acceptability score throughout the storage period.
\end{abstract}

Keywords: Banana, wine, storage, bottles, Alcohol, total soluble solids, sensory evaluation

\section{Introduction}

Banana is one of the economically important fruit crops. It is highly perishable in nature because of textural characteristics and high moisture content. Post harvest losses of banana can be reduced by adopting proper post harvest management practices and processing into value added products. Banana wine is a delicious alcoholic beverage with low alcohol content. The cost of production of banana based alcoholic beverages is much cheaper than other fruit based beverages. Hence, the present study is aimed at evaluating the popular banana varieties of Kerala for wine production and to evaluate the quality of wine during storage.

\section{Materials and Methods}

The present investigation "Biochemical changes of banana wine during storage" was carried out with different varieties of banana. The investigation was carried out in the Department of Post Harvest Technology, College of Horticulture, Vellanikkara, Thrissur during 2019.

Ripe fruits of banana varieties after removal of peel, were sliced into smaller pieces and added with boiled and cooled water in 1:1 and 1:2 ratio. The TSS content of the substrate was raised to $20^{\circ}$ brix by adding cane sugar, followed by addition of yeast $(1.25 \mathrm{~g} / \mathrm{l})$. The must was treated with (KMS) potassium metabisulphate $(0.05 \mathrm{~g} / \mathrm{l})$ for the inhibition of other microorganisms. The entire mass was allowed to ferment for 15 days under anaerobic condition in china clay jar and clarifying agent (egg white) was added at the rate of $1 \mathrm{egg}$ white for 1 litre and it was filtered after one week. Clarified wine was evaluated for its quality. Wine was filled in glass bottles with crown cork, sealed, pasteurized at $82-88{ }^{\circ} \mathrm{C}$ for 2 minutes and stored under ambient conditions for three months.

\section{Wine yield}

After the fermentation, wine was decanted leaving the dead yeast cells and other residues at the bottom of the fermenting jar. The wine yield was expressed as percentage of weight of wine to the initial weight of fermenting substrate including fruit pulp, sugar and water.

$$
\text { Wine yield }=\frac{\text { Weight of wine obtained }}{\text { Initial weight of fermenting substrate }} \times 100
$$




\section{PH}

Standard digital $\mathrm{pH}$ meter was used in determining the $\mathrm{pH}$ of banana wine

\section{Total soluble solids (TSS)}

Total soluble solids were found out using a digital refractometer (range $\left.0-32^{0}\right)$ and expressed as degree brix $\left({ }^{0}\right.$ Brix).

\section{Titratable acidity}

A known weight of sample was mixed with distilled water and made upto a known volume. An aliquot of the filtered solution was titrated against $0.1 \mathrm{~N}$ sodium hydroxide using phenolphthalein as indicator. The acidity was calculated using the formula given below and was expressed as percentage of malic acid (AOAC, 1998) ${ }^{[1]}$

Acidity $=\frac{\text { Normality } \mathrm{x} \text { titre value } \mathrm{x} \text { equivalent weight } \mathrm{x} \text { volume made up }}{\text { Weight of sample } \mathrm{x} \text { aliquot of sample } \mathrm{x} 1000} \times 100$

\section{Ascorbic acid (mg $\left.100 \mathrm{~g}^{-1}\right)$}

Five $\mathrm{ml}$ of the sample was taken and extracted with four per cent oxalic acid. Ascorbic acid was estimated by using standard indicator dye 2, 6- dichlorophenol indophenol and expressed as mg $100 g^{-1}$ of fruit (AOAC, 1998) ${ }^{[1]}$.

Acidity $=\frac{\text { Normality } \mathrm{x} \text { titre value } \mathrm{x} \text { equivalent weight } \mathrm{x} \text { volume made up }}{\text { Weight of sample } \mathrm{x} \text { aliquot of sample } \mathrm{x} 1000} \times 100$

\section{Total phenols}

Folin-Ciocalteu reagent was used in the estimation of phenols. A blue coloured complex (Molybdenum blue) is synthesized when phenols react with phosphomolybdic acid in alkaline medium (Asami et al., 2003) ${ }^{[3]}$.

The wine sample $(5 \mathrm{ml})$ was added to 80 per cent ethanol and centrifuged continuously till it became colourless. The supernatant was collected and pooled. It was evaporated to dryness in hot water bath. Residue was dissolved in distilled water $(5 \mathrm{ml})$. Different aliquots of standards and extracted sample $(0.5 \mathrm{ml})$ were pipetted out into test tubes.

All test tubes including blank was made upto volume $3 \mathrm{ml}$ with distilled water. Folin-Ciocalteau reagent of $0.5 \mathrm{ml}$ was added to all test tubes and allowed to stand for 3 minutes. $2 \mathrm{ml}$ of 20 per cent of sodium carbonate was added to all test tubes and mixed thoroughly and kept at room temperature for 60 minutes. Optical density value was measured in a spectrophotometer at $650 \mathrm{~nm}$. A standard cuve was drawn by taking concentration on $\mathrm{x}$-axis and absorbance on the $\mathrm{y}$ - axis and the concentration of phenols were estimated in the sample.

\section{Alcohol content}

Specific gravity of the fermenting must and specific gravity of wine were determined separately. The alcohol content of wine was calculated by the following formula (Berry, 1998) ${ }^{[4]}$.

Alcohol by volume $(\mathrm{ABV}) \%=\frac{\text { Original Specific Gravity }- \text { final Specific Gravity }}{7.36} \times 1000$

\section{Estimation of yeast population}

Sabouraud's Dextrose Agar media was used for determination of yeast population using different dilution from $10^{-1}$ to $10^{-6}$. One $\mathrm{ml}$ of each dilution was pipetted into a sterile Petridish using a micropipette. About $20 \mathrm{ml}$ of the melted and cooled Sabouraud's Dextrose Agar (SDA) was poured into the Petridish and it was swirled. After solidification, it was kept for incubation at room temperature. Three Petri dishes were kept as replicate for each sample. The Petriplates were incubated at room temperature for 4 to 5 days. The colonies developed were counted and expressed as cfu/ml of the sample (Agarwal and Hasija, 1986) ${ }^{[2]}$.

\section{Estimation of bacterial population}

Bacterial population was estimated using $10^{-5}$ dilution on nutrient agar medium. One $\mathrm{ml}$ of $10^{-5}$ dilution was pipetted into a sterile petridish using a micropipette. About $20 \mathrm{ml}$ of the melted and cooled Nutrient Agar (NA) media was poured into the petridish and it was swirled. After solidification, it was kept for incubation at room temperature. Three petri dishes were kept as replicate for each sample. The petriplates were incubated at room temperature for 48 hours. The colonies developed were counted and expressed as cfu/ml of sample.

\section{Estimation of fungal population}

Fungal population was estimated using 10-3 dilution on Martin Rose Bengal Agar medium. One ml of 10-3 dilution was pipetted into a sterile Petridish using a micropipette. About 20 $\mathrm{ml}$ of the melted and cooled Martin Rose Bengal Agar (MRBA) media was poured into the Petridish and it was swirled. After solidification, it was kept for incubation at room temperature. Three Petri dishes were kept as replicate for each sample. The Petriplates were incubated at room temperature for 4 to 5 days. The colonies developed were counted and expressed as $\mathrm{cfu} / \mathrm{ml}$ of the sample.

\section{Estimation of Lactobacillus spp. population}

Lactobacillus population was estimated using $10^{-4}$ dilution on Lactobacillus MRS Agar medium. One $\mathrm{ml}$ of $10^{-4}$ dilution was pipetted into a sterile petridish using a micropipette. About 20 $\mathrm{ml}$ of the melted and Lactobacillus MRS Agar medium was poured into the Petridish and it was swirled. After solidification, it was kept for incubation at room temperature. Three Petri dishes were kept as replicate for each sample. The Petriplates were incubated at room temperature for 48 hours. The colonies developed were counted and expressed as $\mathrm{cfu} / \mathrm{ml}$ of sample.

\section{Results and Discussion \\ pH}

$\mathrm{pH}$ of all treatments showed an increase trend throughout storage. Wine stored in amber coloured bottles showed higher rate of increase compared to wine stored in plain bottles. After completion of storage, treatment T6 (wine from Karpooravalli stored in amber coloured bottles) recorded highest $\mathrm{pH}$ (3.91) and the lowest (3.75) was observed in $\mathrm{T} 7$ (wine from Yangambi (KM-5) stored in plain bottles).

Higher $\mathrm{pH}$ in wine stored in amber coloured bottles may be due to fall in acidity level in it. Production of hydrogen ions due to breakdown of the acids may have led to increase in the $\mathrm{pH}$ of wine. The rise in $\mathrm{pH}$ due to fall in the acidity may be due to precipitation of acids into salts. Increase in $\mathrm{pH}$ during storage of strawberry wine was reported by Sharma and Joshi, (2002) [13]. The increase in $\mathrm{pH}$ during storage of guava wine was reported by Shankar et al. (2004) ${ }^{[12]}$.

\section{Total soluble solids $\left({ }^{0}\right.$ Brix $)$}

Total soluble solids of banana wine decreased throughout the storage period of 3 months. Wine stored in plain bottles showed higher rate of decrease compared to wine stored in amber coloured bottles. After 3 months of storage, treatment T6 (wine from Karpooravalli stored in amber coloured bottles) recorded 
highest TSS $\left(3.81^{0}\right.$ Brix) and the treatment T3 (wine from Poovan stored in plain bottles) had the lowest $\left(3.60^{0}\right.$ Brix $)$.

Decrease in TSS during storage of wine may be due to conversion of sugar into alcohol by yeast. Constant TSS values after two months of storage may be due to decline in the yeast population. Similar findings were reported in banana wine during storage which had no variation in TSS (Shanmugasundram et al., 2005) ${ }^{[14]}$. Decreasing trend of TSS during storage was reported in jamun wine (Joshi et al., 2011) [6].

\section{Titratable acidity $(\%)$}

Titratable acidity of banana wine showed a decreasing trend during storage. Wine stored in plain bottles showed higher rate of decrease compared to wine stored in amber coloured bottles. After 3 months of storage, treatment T2 (wine from Grand Naine stored in amber coloured bottles) recorded the highest $(0.91 \%)$ titratable acidity and the lowest was observed in T8 (wine from Yangambi (KM-5) stored in amber coloured bottles) $(0.54 \%)$.

Decline in titratable acidity may be due to precipitation of organic acids into their respective salts. Decrease in titratable acidity during storage of banana wine was reported by Brathwaite and Badrie, (2001) ${ }^{[5]}$. Similar findings were also reported during storage of banana wine by Shanmugasundram et al. (2005) ${ }^{[14]}$

\section{Reducing, non-reducing and total sugars}

Reducing, non-reducing and total sugars were not detected during storage. Non detection of sugars may be due to breakdown of sugars for alcohol production by yeast during fermentation of wine and subsequent storage. Similar reduction in sugars during storage were also reported in guava wine (Nikhanj and Kocher, 2011) ${ }^{[9]}$. Shankar et al. (2004) ${ }^{[12]}$, reported that the concentration of reducing sugar decreased in jackfruit wine during storage from 19 to 1.05 percent.

\section{Ascorbic acid (mg 100g-1)}

Ascorbic of banana wine showed a decreasing trend during storage Wine stored in plain bottles showed higher rate of decrease compared to wine stored in amber coloured bottles. At the end of storage, treatment T10 (wine from Palayankodan stored in amber coloured bottles) recorded highest ascorbic

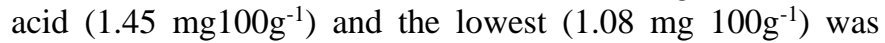
obtained in T1 (wine from Grand Naine stored in plain bottles). Reduction in ascorbic acid content during storage may be due to oxidative reactions and maximum decline in ascorbic acid content in plain bottles may be due to higher rate of oxidative reactions in these bottles. The decreasing trend of ascorbic acid during storage was found in wine prepared from mahua (Madhuca longifolia) (Yadav et al., 2009) ${ }^{[16]}$. Similar reduction in ascorbic acid was also observed in guava wine during storage (Nikhanj and Kocher, 2011) ${ }^{[9]}$.

\section{Total phenols (mg 100g-1)}

Phenol content in banana wine showed a decreasing trend during storage. Wine stored in plain bottles showed higher rate of decrease compared to wine stored in amber coloured bottles. At the end of storage, treatment T7 (wine from Yangambi stored in plain bottles) recorded highest phenols (33.5 $\mathrm{mg} 100 \mathrm{~g}$ ${ }^{1}$ ) and the lowest $\left(25.5 \mathrm{mg} 100 \mathrm{~g}^{-1}\right)$ was obtained in T9 (wine from Palayankodan stored in plain bottles).

Reduction of total phenol content during the storage of wine may be due to loss of reactive hydroxyl groups due to oxidative reactions (Singleton et al., 1999) [15]. Decreasing trend of phenols during storage was reported in jamun wine (Joshi et al., 2011) ${ }^{[6]}$ and also in guava wine (Nikhanj and Kocher, 2011) [9]

\section{Alcohol (\%)}

Alcohol content of banana wine revealed an increasing trend during storage. Wine stored in amber coloured bottles showed higher rate of increase compared to wine stored in plain bottles After 3 months of storage, treatment T10 (wine from Palayankodan stored in amber coloured bottles) recorded the highest alcohol content $(9.85 \%)$ and the lowest $(8.91 \%)$ was in T1(wine from Grand Naine stored in plain bottles).

After 2 months of storage, alcohol production became stable due to non-availability of sugars for the conversion and also due to declining population of yeast and similarly, there was no change in TSS after 2 months of storage Nikhanj and Kocher (2011) ${ }^{[9]}$, reported that there were no changes in alcohol production due to absence of yeast colonies which stopped further fermentation of guava wine. Similar findings were reported in banana wine during storage which had no variation in alcohol content (Shanmugasundram et al., 2005) ${ }^{[14]}$.

\section{Sensory evaluation}

After 30 days of storage, treatment T4 (wine from Poovan stored in amber coloured bottles) had highest overall acceptability score (7.6) and the lowest (5.6) was in T7 (wine from Yangambi stored in plain bottles). Treatment T4 (wine from Poovan stored in amber coloured bottles) had highest overall acceptability score (7.6) and the lowest (5.4) was in T7 (wine from Yangambi stored in plain bottles), after 2 months of storage. After 3 months of storage, treatment T4 (wine from Poovan stored in amber coloured bottles) had highest overall acceptability score (7.4) and the lowest (5.5) was in T7 (wine from Yangambi stored in plain bottles).

Superiority of wine from Poovan as compared to wine from other varieties may be due to its unique flavour, appropriate alcohol content and lower titratable acidity. Higher organoleptic scores for wine stored in amber coloured bottles may be due to lower rate of oxidative reactions which resulted in better flavour and colour. Selli et al., (2002) ${ }^{[8]}$ stated that orange wine stored in bottles with more light penetration had higher oxidative reactions. (Moll, 1991) ${ }^{[7]}$ stated that bottles with less light penetration had lower undesirable changes during wine making and storage.

\section{Yeast population (cfu/ml)}

The yeast population was $0.3 \times 10^{3} \mathrm{cfu} / \mathrm{ml}$ in banana wine from various varieties after 1 month of storage. Thereafter, the yeast population declined and yeast could not be detected after $2^{\text {nd }}$ and $3^{\text {rd }}$ months of storage. The decline in yeast population during storage may be due to depletion of sugars, which serve as food for yeast. Similar decline in yeast population was also reported during storage of guava wine (Nikhanj and Kocher, 2011) ${ }^{[9]}$ and also in banana wine (Saritha, 2011) ${ }^{[11]}$.

\section{Microbial population (cfu/ml)}

Bacteria, fungi and Lactobacillus could not be detected during storage of banana wine. The changes in $\mathrm{pH}$, increase in alcohol content and anaerobic environment might have led to reduction in microbial count of wine. Sahu et al. (2012) ${ }^{[10]}$, noted that during the fermentation period of tendu (Diospyros melanoxylon) fruit wine, there was no detection of bacteria, fungi and other spoilage microorganisms except Saccharomyces cerevisiae. (Saritha, 2011) ${ }^{[11]}$ Reported that during storage of banana wine there was no detection of bacterial and fungal population due to low $\mathrm{pH}$ and high alcohol content which led to decline in microbial population. 
Table 1: Effect of storage conditions on $\mathrm{pH}$, Total soluble solids (TSS) and Titratable acidity of banana wine

\begin{tabular}{|c|c|c|c|c|c|c|c|c|c|c|c|c|}
\hline \multirow{2}{*}{ Treatments } & \multicolumn{4}{|c|}{ pH } & \multicolumn{4}{|c|}{ Total soluble solids $\left({ }^{\circ}\right.$ Brix) } & \multicolumn{4}{|c|}{ Titratable acidity (\%) } \\
\hline & Initial & 1MAS & 2MAS & 3MAS & Initial & 1MAS & 2MAS & 3MAS & Initial & 1MAS & 2MAS & 3MAS \\
\hline $\mathrm{T} 1$ & \multirow[t]{2}{*}{3.73} & 3.74 & 3.76 & 3.77 & \multirow[t]{2}{*}{3.81} & 3.71 & 3.64 & 3.64 & \multirow{2}{*}{1.00} & 0.97 & 0.96 & 0.87 \\
\hline $\mathrm{T} 2$ & & 3.75 & 3.77 & 3.78 & & 3.81 & 3.71 & 3.71 & & 0.98 & 0.97 & 0.91 \\
\hline T3 & \multirow[t]{2}{*}{3.80} & 3.82 & 3.84 & 3.85 & \multirow[t]{2}{*}{3.65} & 3.64 & 3.60 & 3.60 & \multirow{2}{*}{0.76} & 0.70 & 0.66 & 0.61 \\
\hline $\mathrm{T} 4$ & & 3.83 & 3.85 & 3.86 & & 3.71 & 3.64 & 3.64 & & 0.72 & 0.68 & 0.63 \\
\hline T5 & \multirow[t]{2}{*}{3.85} & 3.87 & 3.89 & 3.90 & \multirow[t]{2}{*}{4.5} & 3.81 & 3.74 & 3.74 & \multirow{2}{*}{0.80} & 0.86 & 0.82 & 0.80 \\
\hline T6 & & 3.88 & 3.90 & 3.91 & & 4.07 & 3.91 & 3.91 & & 0.88 & 0.85 & 0.79 \\
\hline $\mathrm{T} 7$ & \multirow[t]{2}{*}{3.69} & 3.72 & 3.74 & 3.75 & \multirow[t]{2}{*}{3.81} & 3.74 & 3.64 & 3.64 & \multirow{2}{*}{0.70} & 0.76 & 0.703 & 0.67 \\
\hline $\mathrm{T} 8$ & & 3.74 & 3.76 & 3.77 & & 3.81 & 3.78 & 3.78 & & 0.79 & 0.71 & 0.65 \\
\hline T9 & \multirow[t]{2}{*}{3.82} & 3.85 & 3.87 & 3.88 & \multirow[t]{2}{*}{3.84} & 3.81 & 3.78 & 3.78 & \multirow{2}{*}{0.82} & 0.81 & 0.76 & 0.77 \\
\hline $\mathrm{T} 10$ & & 3.86 & 3.88 & 3.89 & & 3.84 & 3.82 & 3.82 & & 0.81 & 0.78 & 0.72 \\
\hline $\mathrm{CD}$ & 0.036 & 0.018 & 0.018 & 0.018 & 0.014 & 0.029 & 0.020 & 0.020 & 0.093 & 0.015 & 0.014 & 0.015 \\
\hline
\end{tabular}

MAS-Months after storage

T1- (Grand Naine) wine stored in plain bottles

T2- (Grand Naine) wine stored in amber coloured bottles

T3-(Poovan) wine stored in plain bottles

T4-(Poovan) wine stored in amber coloured bottles

T5-(Karpooravalli) wine stored in plain bottles
T6-(Karpooravalli) wine stored in amber coloured bottles

T7-(Yangambi KM-5) wine stored in plain bottles

T8-(Yangambi KM-5) wine stored in amber coloured bottles

T9-(Palayankodan) wine stored in plain bottles (control)

T10-(Palayankodan) wine stored in amber coloured bottles (control)

Table 2: Effect of storage conditions on ascorbic acid, phenol and alcohol content of banana wine

\begin{tabular}{|c|c|c|c|c|c|c|c|c|c|c|c|c|}
\hline \multirow{2}{*}{ Treatments } & \multicolumn{4}{|c|}{ Ascorbic acid( $\left.\mathrm{mg}^{100 \mathrm{~g}^{-1}}\right)$} & \multicolumn{4}{|c|}{ Phenols (mg 100g ${ }^{-1}$ ) } & \multicolumn{4}{|c|}{ Alcohol (\%) } \\
\hline & Initial & 1MAS & 2MAS & 3MAS & Initial & 1MAS & 2MAS & 3MAS & Initial & 1MAS & 2MAS & 3MAS \\
\hline $\mathrm{T} 1$ & \multirow{2}{*}{1.608} & 1.42 & 1.26 & 1.08 & 4 & 34.50 & 31.00 & 27.16 & \multirow{2}{*}{8.408} & 8.50 & 8.91 & 8.91 \\
\hline $\mathrm{T} 2$ & & 1.44 & 1.28 & 1.12 & 40.5 & 36.33 & 33.00 & 26.00 & & 8.53 & 9.17 & 9.17 \\
\hline T3 & \multirow{2}{*}{1.91} & 1.60 & 1.44 & 1.40 & 4425 & 38.50 & 34.00 & 30.50 & \multirow{2}{*}{9.47} & 9.53 & 9.60 & 9.60 \\
\hline $\mathrm{T} 4$ & & 1.76 & 1.60 & 1.44 & 44.25 & 40.50 & 36.67 & 28.00 & & 9.56 & 9.62 & 9.62 \\
\hline T5 & \multirow{2}{*}{1.98} & 1.50 & 1.44 & 1.26 & \multirow{2}{*}{41.37} & 37.00 & 31.30 & 26.50 & \multirow{2}{*}{$\begin{array}{c}9.369 .36 \\
9.36\end{array}$} & 9.41 & 9.50 & 9.50 \\
\hline T6 & & 1.52 & 1.45 & 1.28 & & 38.83 & 30.33 & 26.33 & & 9.41 & 9.62 & 9.62 \\
\hline T7 & \multirow{2}{*}{1.90} & 1.48 & 1.39 & 1.34 & \multirow{2}{*}{56.25} & 44.33 & 37.00 & 33.50 & \multirow{2}{*}{9.579 .57} & 9.64 & 9.72 & 9.72 \\
\hline T8 & & 1.50 & 1.44 & 1.39 & & 46.50 & 38.00 & 33.00 & & 9.67 & 9.80 & 9.80 \\
\hline T9 & \multirow{2}{*}{1.60} & 1.58 & 1.52 & 1.42 & & 35.00 & 31.00 & 25.50 & \multirow{2}{*}{9.64} & 9.73 & 9.82 & 9.82 \\
\hline T10 & & 1.60 & 1.55 & 1.45 & 42.25 & 38.16 & 32.00 & 27.00 & & 9.75 & 9.85 & 9.85 \\
\hline $\mathrm{CD}$ & 0.015 & 0.017 & 0.017 & 0.017 & 1.316 & 1.301 & 1.616 & 1.282 & 0.087 & 0.013 & 0.104 & 0.104 \\
\hline
\end{tabular}

\section{MAS-Months after storage}

T1- (Grand Naine) wine stored in plain bottles

T2- (Grand Naine) wine stored in amber coloured bottles

T3-(Poovan) wine stored in plain bottles

T4-(Poovan) wine stored in amber coloured bottles

T5-(Karpooravalli) wine stored in plain bottles
T6-(Karpooravalli) wine stored in amber coloured bottles T7-(Yangambi KM-5) wine stored in plain bottles

T8-(Yangambi KM-5) wine stored in amber coloured bottles T9-(Palayankodan) wine stored in plain bottles (control)

T10-(Palayankodan) wine stored in amber coloured bottles (control)

Table 3: Effect of storage conditions on yeast, fungi and bacteria population of banana wine

\begin{tabular}{|c|c|c|c|c|c|c|c|c|c|c|c|c|}
\hline \multirow{2}{*}{ Treatments } & \multicolumn{4}{|c|}{ Yeast $\left(10^{3}\right.$ cfu ml $\left.^{-1}\right)$} & \multicolumn{4}{|c|}{ Fungi $\left(10^{3} \mathrm{cfu} \mathrm{ml}^{-1}\right)$} & \multicolumn{4}{|c|}{ Bacteria ( $\left(10^{5} \mathrm{cfu} \mathrm{ml}^{-1}\right)$} \\
\hline & Initial & MAS & 2MAS & 3MAS & Initial & 1MAS & 2MAS & 3MAS & Initial & 1MAS & 2MAS & 3MAS \\
\hline $\mathrm{T} 1$ & \multirow{2}{*}{3.5} & 0.3 & $\mathrm{a}$ & $\mathrm{a}$ & \multirow{2}{*}{ ND } & $\mathrm{a}$ & $\mathrm{a}$ & $\mathrm{a}$ & \multirow{2}{*}{ ND } & $\mathrm{a}$ & $\mathrm{a}$ & $\mathrm{a}$ \\
\hline $\mathrm{T} 2$ & & 0.3 & $\mathrm{a}$ & $\mathrm{a}$ & & $\mathrm{a}$ & $\mathrm{a}$ & $\mathrm{a}$ & & $\mathrm{a}$ & $\mathrm{a}$ & $\mathrm{a}$ \\
\hline $\mathrm{T} 3$ & \multirow{2}{*}{4.0} & 0.3 & $\mathrm{a}$ & $\mathrm{a}$ & \multirow{2}{*}{$\begin{array}{l}0.5 \\
0.5\end{array}$} & $\mathrm{a}$ & $\mathrm{a}$ & $\mathrm{a}$ & \multirow{2}{*}{0.25} & $\mathrm{a}$ & $\mathrm{a}$ & $\mathrm{a}$ \\
\hline $\mathrm{T} 4$ & & 0.3 & $\mathrm{a}$ & $\mathrm{a}$ & & $\mathrm{a}$ & $\mathrm{a}$ & $\mathrm{a}$ & & $\mathrm{a}$ & $\mathrm{a}$ & $\mathrm{a}$ \\
\hline T5 & \multirow{2}{*}{3.5} & 0.3 & $\mathrm{a}$ & $\mathrm{a}$ & \multirow{2}{*}{ ND } & $\mathrm{a}$ & $\mathrm{a}$ & $\mathrm{a}$ & \multirow{2}{*}{0.25} & $\mathrm{a}$ & $\mathrm{a}$ & $a$ \\
\hline T6 & & 0.3 & $\mathrm{a}$ & $\mathrm{a}$ & & $\mathrm{a}$ & $\mathrm{a}$ & $\mathrm{a}$ & & $\mathrm{a}$ & $\mathrm{a}$ & $\mathrm{a}$ \\
\hline T7 & \multirow{2}{*}{3.5} & 0.3 & $a$ & $\mathrm{a}$ & \multirow{2}{*}{ ND } & $a$ & $\mathrm{a}$ & $a$ & \multirow[b]{2}{*}{ ND } & $a$ & $\mathrm{a}$ & $a$ \\
\hline T8 & & 0.3 & $a$ & $\mathrm{a}$ & & $a$ & $\mathrm{a}$ & $\mathrm{a}$ & & $\mathrm{a}$ & $\mathrm{a}$ & $a$ \\
\hline T9 & \multirow{2}{*}{3.2} & 0.3 & $\mathrm{a}$ & $\mathrm{a}$ & \multirow{2}{*}{ ND } & $\mathrm{a}$ & $\mathrm{a}$ & $a$ & \multirow{2}{*}{ ND } & $\mathrm{a}$ & $\mathrm{a}$ & $\mathrm{a}$ \\
\hline T10 & & 0.3 & $\mathrm{a}$ & $\mathrm{a}$ & & $a$ & $\mathrm{a}$ & $\mathrm{a}$ & & $\mathrm{a}$ & $\mathrm{a}$ & $a$ \\
\hline $\mathrm{CD}$ & - & - & - & - & - & - & - & - & - & - & - & - \\
\hline
\end{tabular}

MAS-Months after storage

a- absent

T1- (Grand Naine) wine stored in plain bottles

T2- (Grand Naine) wine stored in amber coloured bottles

T3-(Poovan) wine stored in plain bottles

T4--(Poovan) wine stored in amber coloured bottles

T5-(Karpooravalli) wine stored in plain bottles
T6-(Karpooravalli) wine stored in amber coloured bottles T7-(Yangambi KM-5) wine stored in plain bottles T8-(Yangambi KM-5) wine stored in amber coloured bottles T9-(Palyankodan) wine stored in plain bottles (control)

T10-(Palyankodan) wine stored in amber coloured bottles (control) 
Table 4: Effect of storage conditions on Lactobacillus population of banana wine

\begin{tabular}{|c|c|c|c|c|}
\hline \multirow{2}{*}{ Treatments } & \multicolumn{4}{|c|}{ Lactobacillus $\left(10^{4} \mathrm{cfu} \mathrm{ml}^{-1}\right)$} \\
\hline & Initial & 1MAS & 2MAS & 3MAS \\
\hline T1 & \multirow{2}{*}{ a } & $\mathrm{a}$ & $\mathrm{a}$ & $\mathrm{a}$ \\
\hline $\mathrm{T} 2$ & & $\mathrm{a}$ & $\mathrm{a}$ & $\mathrm{a}$ \\
\hline T3 & \multirow{2}{*}{ a } & $\mathrm{a}$ & $\mathrm{a}$ & $\mathrm{a}$ \\
\hline T4 & & $\mathrm{a}$ & $\mathrm{a}$ & $\mathrm{a}$ \\
\hline T5 & \multirow{2}{*}{ a } & $\mathrm{a}$ & $\mathrm{a}$ & $\mathrm{a}$ \\
\hline T6 & & $\mathrm{a}$ & $\mathrm{a}$ & $\mathrm{a}$ \\
\hline T7 & \multirow{2}{*}{0.25} & $\mathrm{a}$ & $\mathrm{a}$ & $\mathrm{a}$ \\
\hline T8 & & $\mathrm{a}$ & $\mathrm{a}$ & $\mathrm{a}$ \\
\hline T9 & \multirow{2}{*}{ a } & $\mathrm{a}$ & $\mathrm{a}$ & $\mathrm{a}$ \\
\hline $\mathrm{T} 10$ & & $\mathrm{a}$ & $\mathrm{a}$ & $\mathrm{a}$ \\
\hline $\mathrm{CD}$ & - & - & - & - \\
\hline
\end{tabular}

MAS- Months after storage

ND- Not detected

T1- (Grand Naine) wine stored in plain bottles

T2- (Grand Naine) wine stored in amber coloured bottles

T3-(Poovan) wine stored in plain bottles

T4--(Poovan) wine stored in amber coloured bottles

T5-(Karpooravalli) wine stored in plain bottles (control)
T6-(Karpooravalli) wine stored in amber coloured bottles T7-(Yangambi KM-5) wine stored in plain bottles T8-(Yangambi KM-5) wine stored in amber coloured bottles T9-(Palyankodan) wine stored in plain bottles (control) T10-(Palyankodan) wine stored in amber coloured bottles

Table 5: Effect of storage on organoleptic quality of banana wine (1MAS)

\begin{tabular}{|c|c|c|c|c|c|c|c|c|}
\hline Treatments & Appearance & Colour & Flavour & Odour & Body & Taste & After taste & Over all acceptability \\
\hline T1 & 6.5 & 6.3 & 6.5 & 6.4 & 6.3 & 6.7 & 6.5 & 6.7 \\
\hline T2 & 6.8 & 7.2 & 6.9 & 7.0 & 6.4 & 6.7 & 7.4 & 7.3 \\
\hline T3 & 6.5 & 6.6 & 6.6 & 6.5 & 6.7 & 6.4 & 6.3 & 6.5 \\
\hline T4 & 7.4 & 7.1 & 7.4 & 7.4 & 7.6 & 7.3 & 7.6 & 7.6 \\
\hline T5 & 5.6 & 5.8 & 5.9 & 6.2 & 5.7 & 6.0 & 6.2 & 5.6 \\
\hline T6 & 6.3 & 6.6 & 6.5 & 6.5 & 6.4 & 6.4 & 6.5 & 6.6 \\
\hline T7 & 5.4 & 5.7 & 5.5 & 5.4 & 5.5 & 5.4 & 5.5 & 5.6 \\
\hline T8 & 5.7 & 6.1 & 5.9 & 6 & 6.4 & 6.0 & 5.8 & 6.1 \\
\hline T9 & 6.4 & 6.9 & 6.5 & 6.5 & 6.7 & 6.2 & 6.5 & 6.4 \\
\hline T10 & 6.7 & 7.1 & 7.0 & 6.8 & 6.8 & 6.4 & 6.8 & 6.8 \\
\hline Kendal's W test & 0.467 & 0.504 & 0.417 & 0.412 & 0.452 & 0.406 & 0.55 & .480 \\
\hline
\end{tabular}

T1- (Grand Naine) wine stored in plain bottles

\begin{tabular}{c|c|c|c|c}
0.412 & 0.452 & 0.406 & 0.55 & .480 \\
\multicolumn{2}{l}{ T6-(Karpooravalli) wine stored in amber coloured bottles }
\end{tabular}

T2- (Grand Naine) wine stored in amber coloured bottles

T3-(Poovan) wine stored in plain bottles

T4--(Poovan) wine stored in amber coloured bottles

-(Yangambi KM-5) wine stored in plain bottle

T8-(Yangambi KM-5) wine stored in amber coloured bottles

T9-(Palyankodan) wine stored in plain bottles (control)

T5-(Karpooravalli) wine stored in plain bottles

T10-(Palyankodan) wine stored in amber coloured bottles

(control) MAS- Months after storage

Table 6: Effect of storage on organoleptic quality of banana wine (2MAS)

\begin{tabular}{|c|c|c|c|c|c|c|c|c|}
\hline Treatments & Appearance & Colour & Flavour & Odour & Body & Taste & After taste & Over all acceptability \\
\hline T1 & 6.6 & 6.2 & 6.5 & 6.7 & 6.6 & 6.3 & 6.6 & 6.7 \\
\hline T2 & 6.6 & 7.1 & 7.4 & 7.2 & 6.9 & 7.4 & 6.7 & 6.6 \\
\hline T3 & 6.4 & 6.1 & 6.7 & 6.5 & 6.6 & 6.7 & 6.4 & 6.4 \\
\hline T4 & 7.3 & 7.2 & 7.5 & 7.7 & 7.7 & 7.6 & 7.4 & 7.6 \\
\hline T5 & 5.9 & 5.9 & 6.2 & 6.4 & 5.8 & 6.4 & 5.5 & 6.0 \\
\hline T6 & 6.4 & 6.5 & 6.3 & 6.4 & 6.6 & 6.6 & 6.5 & 6.6 \\
\hline T7 & 5.3 & 5.6 & 5.4 & 5.7 & 5.7 & 5.0 & 5.6 & 5.4 \\
\hline T8 & 6.0 & 6.3 & 6.2 & 5.8 & 6.1 & 6.0 & 6.0 & 6.1 \\
\hline T9 & 6.5 & 6.5 & 6.4 & 6.5 & 6.4 & 6.3 & 6.5 & 6.4 \\
\hline T10 & 6.7 & 6.7 & 6.6 & 7.0 & 6.8 & 7.2 & 6.8 & 6.6 \\
\hline Kendal's W test & 0.36 & 0.412 & 0.461 & 0.443 & 0.396 & 0.658 & 0.424 & 0.435 \\
\hline
\end{tabular}

T1- (Grand Naine) wine stored in plain bottles

T6-(Karpooravalli) wine stored in amber coloured bottles

T2- (Grand Naine) wine stored in amber coloured bottles

T3-(Poovan) wine stored in plain bottles

T4--(Poovan) wine stored in amber coloured bottles

T5-(Karpooravalli) wine stored in plain bottles

T7-(Yangambi KM-5) wine stored in plain bottles

T8-(Yangambi KM-5) wine stored in amber coloured bottles

T9-(Palyankodan) wine stored in plain bottles (control)

T10-(Palyankodan) wine stored in amber coloured bottles 
Table 7: Effect of storage on organoleptic quality of banana wine (3MAS)

\begin{tabular}{|c|c|c|c|c|c|c|c|c|}
\hline Treatments & Appearance & Colour & Flavour & Odour & Body & Taste & After taste & Over all acceptability \\
\hline T1 & 6.5 & 6.5 & 6.6 & 6.6 & 6.6 & 6.6 & 6.3 & 6.5 \\
\hline T2 & 6.9 & 7.3 & 7.0 & 6.9 & 7.3 & 6.5 & 6.3 & 7.2 \\
\hline T3 & 6.6 & 6.5 & 6.4 & 6.5 & 6.3 & 6.6 & 6.3 & 6.7 \\
\hline T4 & 7.5 & 7.4 & 7.6 & 7.8 & 7.5 & 7.1 & 6.3 & 7.4 \\
\hline T5 & 6.0 & 6.2 & 5.7 & 6.1 & 5.9 & 5.8 & 6.3 & 6.0 \\
\hline T6 & 6.5 & 6.3 & 6.4 & 6.3 & 6.4 & 6.7 & 6.3 & 6.2 \\
\hline T7 & 5.5 & 5.5 & 5.4 & 5.7 & 5.3 & 5.4 & 6.3 & 5.5 \\
\hline T8 & 5.8 & 6.0 & 6.2 & 6.2 & 6.1 & 5.8 & 6.3 & 6.0 \\
\hline T9 & 6.2 & 6.4 & 6.6 & 6.2 & 6.7 & 6.7 & 6.3 & 6.7 \\
\hline T10 & 6.8 & 6.8 & 6.7 & 6.9 & 6.6 & 6.5 & 6.3 & 7.0 \\
\hline Kendal's W test & 0.483 & 0.438 & 0.531 & 0.444 & 0.538 & 0.429 & 0.282 & 0.467 \\
\hline
\end{tabular}

T1- (Grand Naine) wine stored in plain bottles

T6-(Karpooravalli) wine stored in amber coloured bottles

T2- (Grand Naine) wine stored in amber coloured bottles T7-(Yangambi KM-5) wine stored in plain bottles

T3-(Poovan) wine stored in plain bottles

T4--(Poovan) wine stored in amber coloured bottles

T5-(Karpooravalli) wine stored in plain bottles

(control) MAS- Months after storage

\section{References}

1. AOAC. Official and Tentative Methods of Analysis (13th Ed.). Association of Official Analytical Chemists. Washington DC, 1998, 1018.

2. Agarwal GP, Hasija SK. Microorganisms in the Laboratory. Print House India Ltd. Lucknow, 1986, 155.

3. Asami DK, Hong YJ, Barrett DM, Mitchell AE. Comparison of the total phenolic and ascorbic acid content of freeze-dried and air dried marionberry, strawberry and corn grown using conventional, organic and sustainable agricultural practices. Journal of Agricultural chemistry. 2003; 51:1237-1241.

4. Berry CJJ, Berry CJ. First steps in winemaking. Nexus Special Interests, 1998.

5. Brathwaite RE, Badrie N. Quality changes in banana (Musa acuminata) wines on adding pectolase and passion fruit. J Food Sci. Technol. 2001; 38(4):381-384.

6. Joshi VK, Sharma R, Girdher A, Abrol G. Effect of dilution and maturation on physico-chemical and sensory of jamun (Black plum) wine. Indian Journal of Natural Product and Resources. 2011; 3(2):222-227.

7. Moll M. Beers and Coolers, Sprenger-Verlag, Berlin, 1991, 495.

8. Mo Selli S, Canbaş A, Ünal U. Effect of bottle colour and storage conditions on browning of orange wine. Food/Nahrung. 2002; 46(2):64-67.

9. Nikhanj, Kocher. Fermentative Production of GuavaWine (Psidium guajava L.) Using S. cerevisiae MTCC 11815. Current Nutrition and Food Science. 2011; 11:2130.

10. Sahu UC, Panda SK, Mohapatra UB, Ray RC. Preparation and evaluation of wine from tendu (Diospyros melanoxylon L) fruits with antioxidants. Int. J Food Fermentation Technol. 2012; 2(2):167-178.

11. Saritha EV. Process standardization for banana wine. MSc. (Home Science) thesis, Kerala Agricultural University, Thrissur, 2011, 151.

12. Shankar S, Dilip J, Narayana Y. Changes in chemical composition of guava wine during storage. Indian Food Packer. 2004; 12:56-58.

13. Sharma S, Joshi VK. Effect of maturation on the physicochemical and sensory quality of strawberry wine. J Sci. Industrial Res. 2002; 62:601-608.

14. Shanmugasundaram S, John Kennedy Z, Thirupathi V, Narayanan L. Qualitative changes in banana pulp and juice during wine making process. The Indian J Nutr. Dietet. 2005; 42:560-570.

15. Singleton VL, Orthofer R, Lamuela-Raventós RM. Analysis of total phenols and other oxidation substrates and antioxidants by means of folin-ciocalteu reagent. In Methods in enzymology Academic press. 1999; 299:152178.

16. Yadav P, Garage N, Diwedi DH. Standardization of pretreatment conditions for mahua wine preparation. Journal of Eco-friendly Agriculture. 2009; 4(1):88-92. 